\title{
Efficiency Analysis of CBA Full-scale Hospital Waste Water Treatments in Indonesia Using Combined Biological AOP System: Investigation on Operating Conditions, Treatment Efficiency and Energy
}

\author{
Hadi Pranoto ${ }^{1}$, Rame Rame ${ }^{2}$, EvFajar Wuryadi ${ }^{3}$, Mohamad Sofie ${ }^{4}$, Ary Sulistyo Utomo ${ }^{4}$, and Budi Haryo \\ Raharjo ${ }^{4}$ \\ ${ }^{1}$ Bartec Utama Mandiri, Semarang - Indonesia \\ ${ }^{2}$ Center of Industrial Pollution Prevention Technology, Semarang-Indonesia \\ ${ }^{3}$ Cahaya Kilau Kencana, Semarang- Indonesia \\ ${ }^{4}$ ATEM, Semarang-Indonesia
}

\begin{abstract}
Combined biological AOP system, or CBA, are increasingly being used in Indonesia to treatment hospital waste water, that are otherwise difficult to treatment in conventional methods. CBA catalytic ozonation are now used for over 579 hospitals, making this tool a major phenomenon for high adopt hospital waste water treatments in Indonesia, and one that has experienced great expansion over the past three years. The question of whether the CBA is a good or a bad tool for the treatment hospital waste water depends on many parameters. To respond to this question, it is necessary to investigate on operating conditions, but it is also very important to gather more data and conduct further research on treatment efficiency and energy. In this paper, we examined and discuss to gain a better understanding of the CBA environmental technology and of its impacts. About 100 CBA Full-scale Hospital waste water treatments have been investigated, and it was in Indonesia from eight provinces. CBA demonstrate good removal efficiency of macropollutants from hospital waste water and meet the requirements as per LH R.I. Number 5 Year 2014 on Wastewater Quality Standard and LHK R.I. Number P.68 / Menlhk / Setjen / Kum.1 / 8/2016 Concerning the Quality Standards of Domestic Waste Water. Various parameters of macro-pollutants such as $\mathrm{pH}$, temperature, TDS, TSS, BOD 5, COD, oil fat, and MBAS also amonia nitrogen and total coliform were analysed to identify the performance of CBA. We obtained the average energy consumption per cycle is $0.504 \mathrm{kWh}$, capacity $3 / 4 \mathrm{~m}^{3} /$ hours which treatment cost $\mathrm{Rp} 1.478 / \mathrm{m}^{3}$ and $60,96 \%-94,00 \%$ removal efficiency of macro-pollutants. CBA catalytic ozonation reported here is very efficient and environmental friendly for treatment hospital waste water.
\end{abstract}

Keywords: CBA; efficiency; operating conditions; treatment; energy.

\section{Introduction}

The hazardous chemicals and the harmful microbes contents are a most pollutant type found in hospital and community health centre [1-3]. The hazardous chemicals sources usually come from pharmaceutical active compounds ( $\mathrm{PhACs}$ ), heavy metals, detergents, X-ray contrast media, and disinfection agents [4-7]. Harmful microbes sources could come from the pathogenic microorganisms such as viruses, bacteria, fungi, and protozoans. They not only cause a major environmental problem, but also threat human health due to its potential toxicity and highly infectious contamination $[1-3,8,9]$. Waste water treatment is required to prevent severe contamination in human health suffering from toxicity and infectious. As hazardous chemicals and the harmful microbes have difficult to treatment in conventional methods, are nonbiodegradable and accumulative in environment and have an increased risk of pathogen dissemination and in antibiotic resistance which spread into the environment, it is highly important to adopt alternative strategies of advanced waste water treatment.

CBA is a technology that uses the advanced oxydation process, as the main process $[10,11]$. CBA produces a strong oxidizing hydroxyl radical, a free radical that has a very high oxidation potential $(2.8 \mathrm{eV})$, far exceeding ozone $(2.07 \mathrm{eV})$ which is very effective for decomposing organic contaminants, killing harmful microbes and destroying hazardous chemicals. Radical Hydroxyl is produced from the reaction between Ozone $\left(\mathrm{O}_{3}\right)$ and catalyst at the present of water. As a final result of CBA

* Corresponding author: rameatmopawiro@gmail.com 
is only water and a small amount of carbon dioxide will be obtained [12-14].

Combined biological advanced oxidation processes system, or CBA, are increasingly being used in Indonesia to treatment hospital waste water, that are otherwise difficult to treatment in conventional methods. CBA bases catalytic ozonation are now used for over 579 hospitals, making this tool a major phenomenon for high adopt hospital waste water treatments in Indonesia, and one that has experienced great expansion over the past three years. CBA full-scale hospital and community health centre wastewater treatments in Indonesia uses the biological and the physical pre-treatment, followed by advanced oxidation process and then followed by granulated activated carbon (GAC) and powdered activated carbon (PAC) filtration $[10,11,15]$. This efforts have been carried out in Indonesia and considered as community health centre which provides healthcare for population on subdistrict level. CBA represent not only produce hydroxyl radical, but are themselves determined as fast direct treatment for hospital and community health centre wastewater.

In recent years, hospital and community health centre have gained most of interest in the wastewater pollution as they increase and produce much more hazardous chemicals, harmful microbes and other type of pollutions and are associated with threat human health concern.

The question of whether the CBA is a good or a bad tool for the treatment hospital waste water depends on many parameters. To respond to this question, it is necessary to investigate the treatment hospital and community health centre wastewater that meet the the requirements as per LH R.I. Number 5 Year 2014 on wastewater quality standard and LHK R.I. Number P.68 / Menlhk / Setjen / Kum.1 / 8/2016 concerning the quality standards of domestic waste water from full-scale CBA system. This study aimed to investigate on operating conditions of $\mathrm{CBA}$, and it is also very important to gather more data and conduct further research on treatment efficiency and energy. In this paper, we examined and discuss to gain a better understanding of the CBA as environmental technology and of its impacts.

\section{Materials and Method}

\subsection{Operating conditions of CBA}

The full-scale CBA from workshoop of manufacturer (kindly provided by BUMA) and CBA systems that have been operated on hospitals and community health centre waste water treatments have been choosed to investigate on operating conditions.

\subsection{Treatment efficiency analysis of CBA}

The Various parameters of macro-pollutants such as $\mathrm{pH}$, temperature, TDS, TSS, $\mathrm{BOD}_{5}, \mathrm{COD}$, oil fat, and MBAS also amonia nitrogen and total coliform were analysed to identify the performance of CBA. About 100 CBA Fullscale hospitals and community health centre waste water treatments have been investigated, and it The content of pollutants in from 100 wastewater was analyzed as understanding the removal efficiency of macro-pollutants from hospital waste water. For all CBA parameters analyses, from input before treatment $\mathrm{CBA}$ and output after treatment $\mathrm{CBA}$ were determined according the requirements as per LH R.I. Number 5 Year 2014 on Wastewater Quality Standard and LHK R.I. Number P.68 / Menlhk / Setjen / Kum.1 / 8/2016 Concerning the Quality Standards of Domestic Waste Water.

\subsection{Assessment of efficiency energy from CBA}

For gather more data and conduct further research on efficiency energy of CBA, all energy consumption from unit of CBA were determined. Analysis was performed base quantity of power and time elapsed during one cycle of CBA process.

\section{Results and Discussion}

\subsection{Operating conditions of CBA}

Pre-treatment and post-treatment used to degrade before and after advanced oxidation processes are consistent with CBA used for the destruction of hazardous chemicals and the harmful microbes contents from hospitals and community health centre waste water [1619], as we have described below (Fig. 1). The full-scale CBA from workshoop of manufacturer (Fig. 2) and CBA systems that have been operated on hospitals (Fig. 3) and community health centre waste water (Fig. 4).

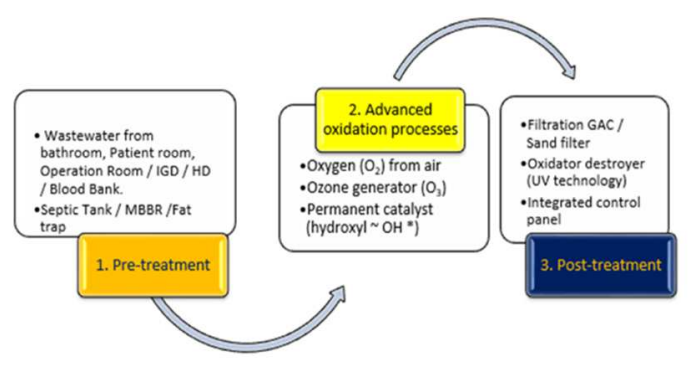

Fig. 1. Schematic representation of the process stages from CBA. 


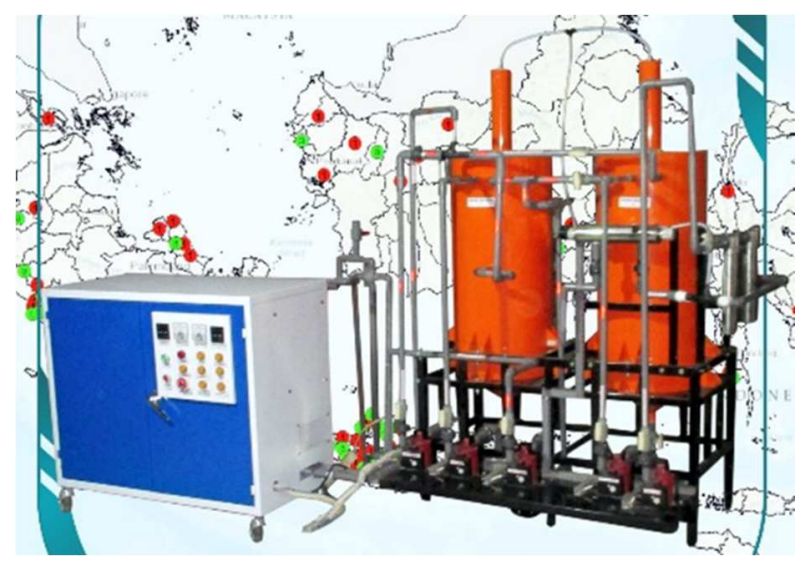

Fig. 2. The full-scale CBA from workshoop of manufacturer.

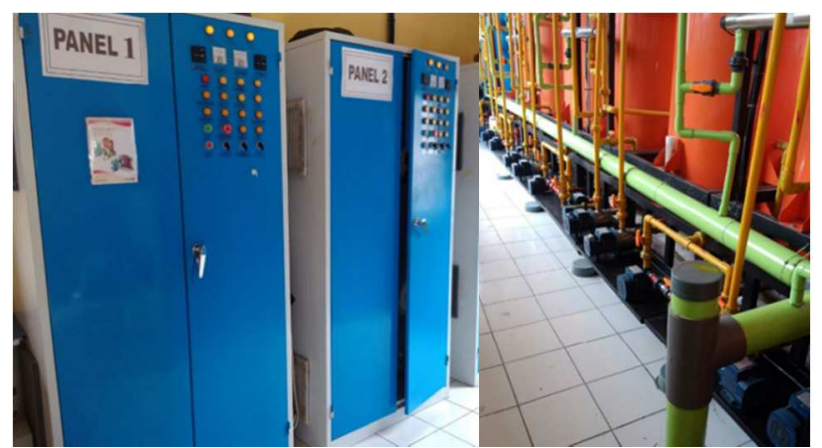

Fig. 3. The full-scale CBA from hospitals.

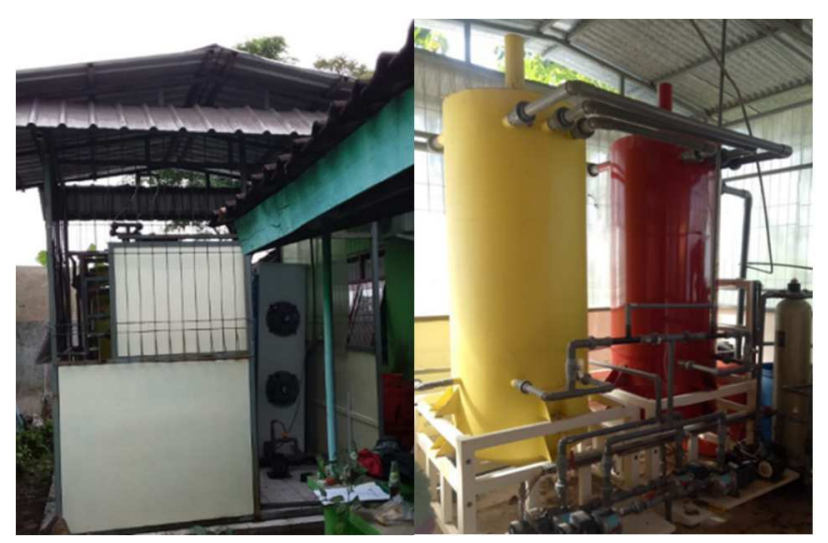

Fig. 4. The full-scale CBA from community health centre.

Methods / Workflow from Wastewater Treatment using CBA include:

\subsubsection{Pre-treatment}

Before the waste water enters the AOP system, wastewater must meet some conditions acceptable to the system. Some things that can disrupt the performance of the AOP system must be neutralized first, such as excessive solid / inorganic waste [20,21]. For that need to be installed box colector and filter. Then the pump to drain the waste water from mini colector to equalization tank. The pump working system is affected by the water level sensor so that if the water is less then the pump will stop. Pre-treatment stage serves to eliminate solid waste and reduce the value of $\mathrm{COD}, \mathrm{BOD}_{5}$, TDS, and TSS and other contaminants.

\subsubsection{Advanced oxidation processes (AOP)}

This system is equipped with several pumps, namely inlet pump, serves to drain the waste water from equalization tank to Reaction tank. The working system is affected by the water level sensor so that if the waste water is less then the inlet pump will stop. Circulatory pumps to distribute wastewater present in Primary tanks to the Catalytic Ozone system. Performance of Catalytic Ozone System will be effective when ozone $\left(\mathrm{O}_{3}\right)$ is mixed with wastewater in the presence of a permanent catalyst which will produce a hydroxyl radical $(\mathrm{OH} *)$. The diffuser / venturi as an injection system will increase the contact surface area between the waste water, ozone $\left(\mathrm{O}_{3}\right)$, and the catalyst to produce a maximum hydroxyl radical. This hydroxyl radical $(\mathrm{OH} *)$, is essential in the process of decomposition and destruction of chemical / medicinal chemicals, pathogenic microbes, and organic contaminants in wastewater $[1,14,22]$. Oxygen $\left(\mathrm{O}_{2}\right)$ with a high concentration used as an ozone generating unit $\left(\mathrm{O}_{3}\right)$ input is supplied from free air using Oxygen generating units $\left(\mathrm{O}_{2}\right)$. The transfer pump serves as a means of distributing wastewater which has mixed hydroxyl radical $(\mathrm{OH} *)$ in the previous stage into the Secondary tank to complete the reaction of decomposition process and the destruction of contamination in the waste water.

\subsubsection{Post-treatment}

The filter pump for draining the water coming from the Secondary tank to the filtration process according to the final output specification. Filtration serves to reduce metal / inorganic contamination. Then flowed to the oxidizer destroyer for the process of removing the remaining oxidizer $\left(\mathrm{O}_{3}\right)$. The filter pump may also serve as a clean water distributor for the washing requirements of the filtration unit.

\subsection{Treatment efficiency analysis of CBA}

Removal efficiency of macro-pollutants from hospital and community health centre waste water were analyzed from parameters value according to the requirements as per LH R.I. Number 5 Year 2014 on Wastewater Quality Standard and LHK R.I. Number P.68 / Menlhk / Setjen / Kum.1 / 8/2016 Concerning the Quality Standards of Domestic Waste Water such as $\mathrm{pH}$, temperature, TDS, TSS, $\mathrm{BOD}_{5}, \mathrm{COD}$, oil fat, and MBAS also amonia nitrogen and total coliform, etc. About 100 CBA Fullscale Hospital waste water treatments have been 
investigated, and it was in Indonesia from eight provinces (Central Java, West Sumatra, NTB, East Java, West Kalimantan, West Java, DKI Jakarta, Bangka Belitung).

Table 1. Analysisis of macro-pollutants in 100 CBA Full-scale hospital and community health centre waste water.

\begin{tabular}{|c|c|c|c|c|c|}
\hline Parameter & Standard & Input & Output & $\begin{array}{l}\text { Decrease } \\
\text { efficiency }\end{array}$ & $\begin{array}{l}\text { Average } \\
\text { efficiency } \\
\text { decrease }\end{array}$ \\
\hline $\begin{array}{c}\text { a Dissolved } \\
\text { solids (TDS) } \\
\text { (mg } / \mathrm{L} \text { ) }\end{array}$ & 2000 & 2918 & 285 & $90.23 \%$ & $60.96 \%$ \\
\hline $\begin{array}{c}\text { b.Suspended } \\
\text { solids (TSS) } \\
\text { (mg } / \mathrm{L})\end{array}$ & 30 & 171 & 2 & $98.83 \%$ & $77.21 \%$ \\
\hline $\begin{array}{c}\text { c.BOD } \\
\text { (mg } / \mathrm{L})\end{array}$ & 50 & 208 & 3.14 & $98.49 \%$ & $80.28 \%$ \\
\hline $\begin{array}{c}\text { d.COD } \\
\text { (mg } / \mathrm{L})\end{array}$ & 80 & 595 & 10.91 & $98.16 \%$ & $71.24 \%$ \\
\hline $\begin{array}{c}\text { e.Oil and fat } \\
\text { (mg } / \mathrm{L})\end{array}$ & 5 & 8.22 & 2.07 & $74.82 \%$ & $74.82 \%$ \\
\hline $\begin{array}{c}\text { f.Ammonia } \\
\text { nitrogen (mg }\end{array}$ & 10 & 59.34 & 3.45 & $94.18 \%$ & $77.70 \%$ \\
\hline $\begin{array}{c}\text { g. Total } \\
\text { coliform } \\
\text { (MPN } \\
\text { l00ml) }\end{array}$ & 3000 & $9 \times$ & 220 & $99.99 \%$ & $94 \%$ \\
\hline
\end{tabular}

Evaluation removal efficiency of macro-pollutants from the input to output was analyzed on CBA systems manufacturer (Table. 1). Results are shown as the highest input, output, decrease efficiency, and average efficiency decrease from 100 CBA systems. (a) Dissolved solids in the output decreased until $90.23 \%$, to $285 \mathrm{mg} / \mathrm{L}$ from highest input $2918 \mathrm{mg} / \mathrm{L}$ in waste water and $60.96 \%$ in average efficiency decrease. (b) Suspended solids decreased from $171 \mathrm{mg} / \mathrm{L}$ to $2 \mathrm{mg} / \mathrm{L}$ and $98.83 \%$ in decrease efficiency and average efficiency decrease $77.21 \%$. (c) The number of $\mathrm{BOD}_{5}$ from input decreased from $208 \mathrm{mg} / \mathrm{L}$ to $3.14 \mathrm{mg} / \mathrm{L}$ on output. Whilst the decrease efficiency $98.49 \%$ and average efficiency decrease $80.28 \%$. (d) Also, the COD from input decreased from $595 \mathrm{mg} / \mathrm{L}$ to $80 \mathrm{mg} / \mathrm{L}$. The amount of total chemical generated waste water was significantly higher, with $387 \mathrm{mg} / \mathrm{L}$. Whilst the decrease efficiency COD $98.16 \%$ and average efficiency decrease $71.24 \%$. (e) Oil and fat decreased from $8.22 \mathrm{mg} / \mathrm{L}$ to $2.07 \mathrm{mg} / \mathrm{L}$ and $74.82 \%$ in decrease efficiency and average efficiency decrease. (f) The number of ammonia nitrogen from input decreased from $59.34 \mathrm{mg} / \mathrm{L}$ to $3.45 \mathrm{mg} / \mathrm{L}$ on output. Whilst the decrease efficiency $94.18 \%$ and average efficiency decrease $77.70 \%$. (f) Total coliform from the waste water on input decreased in huge $(99.99 \%)$. In total $9 \times 10^{6}$ can be decreased per $100 \mathrm{~mL}$ into 220 , which corresponds to $94 \%$ average efficiency decrease per input. The amount of total coliform decreased in wastewater was significantly higher.

The percentage decreased of other parameter, as well as to meet the requirements as per LH R.I. Number 5 Year 2014 on Wastewater Quality Standard and LHK R.I. Number P.68 / Menlhk / Setjen / Kum.1 / 8/2016 Concerning the Quality Standards of Domestic Waste
Water such as $\mathrm{pH}$, temperature, and MBAS, etc., were slightly decreased in output compared to standard. These data further indicate that CBA full-scale in hospital and community health centre are functional. The performance of CBA demonstrate good removal efficiency of macropollutants from hospital waste water and meet the requirements as government regulation.

\subsection{Assessment of efficiency energy from CBA}

For gather more data and conduct further research on efficiency energy of CBA, all energy consumption from unit of CBA were determined. Analysis was performed base quantity of power and time elapsed during one cycle of CBA process (Table. 2).

Table 2. Analysis energy consumption base quantity of power and cycle time during one cycle of CBA process.

\begin{tabular}{|l|c|c|c|c|}
\hline \multicolumn{1}{|c|}{ Name of equipment } & $\begin{array}{c}\text { Power } \\
(\mathrm{kW})\end{array}$ & $\begin{array}{c}\text { Cycle } \\
\text { time } \\
\text { (hours) }\end{array}$ & $\begin{array}{c}\text { Power } \\
\text { consumption } \\
(\mathrm{kWh})\end{array}$ & $\begin{array}{c}\text { Cost (Rp) } \\
1.467 / \mathrm{kWh}\end{array}$ \\
\hline Inlet pump & 0.300 & $10 / 60$ & 0.050 & 73.35 \\
\hline $\begin{array}{l}\text { Circulating pumps, } \\
\text { Ozone generating units (O3) } \\
\text { Oxygen generating unit (O2) }\end{array}$ & 1.275 & $15 / 60$ & 0.319 & 467.97 \\
\hline Transfer pump & 0.425 & $7 / 60$ & 0.050 & 73.35 \\
\hline Filter pump and destructor & 0.425 & $12 / 60$ & 0.085 & 124.70 \\
\hline
\end{tabular}

The capacity of the unit at the pre-treatment and posttreatment stage is adjusted to the characteristics of raw materials and final product specifications. AOP system is adjusted as needed by calculation based on ozone dose requirement, process flow, and product type. . Adjust ozone capacity is a typical feature of CBA, which ozone capacity $10 \mathrm{~g} / \mathrm{h}(5 \mathrm{~g} / \mathrm{m} 3=5 \mathrm{mg} / \mathrm{L}=5 \mathrm{ppm})$ showed that wastewater treatment capacity $=60 / 44$ x 500 liter $=$ 682 liter / hour and Wastewater treatment capacity $=6 \mathrm{x}$ $5(44 / 60) \times 500$ liter $=11,000$ liters $/$ day $\sim 11 \mathrm{~m}^{3} /$ day $(5$ breaks for 22 minutes). Operating price of CBA systems revealed a $\mathrm{Rp} 1.478 / \mathrm{m}^{3}$. These data indicate that $\mathrm{CBA}$ systems consumed very low energy in the treatement of hospitals and community health centre waste water.

\section{Summary}

Altogether, we have presented a portable compact platform to treatment large numbers of hospital waste water, with reduced work-load, handling steps, and operational costs. This system is easily scalable and can be adapted to automatization and online tagging. CBA demonstrate good removal efficiency of macro-pollutants from hospital waste water and meet the requirements as per LH R.I. Number 5 Year 2014 on Wastewater Quality Standard and LHK R.I. Number P.68 / Menlhk / Setjen / Kum.1 / 8/2016 Concerning the Quality Standards of Domestic Waste Water. Various parameters of macropollutants such as $\mathrm{pH}$, temperature, TDS, TSS, $\mathrm{BOD}_{5}$, COD, oil fat, and MBAS also amonia nitrogen and total coliform were analysed to identify the performance of CBA. We obtained the average energy consumption per 
cycle is $0.504 \mathrm{kWh}$, capacity $3 / 4 \mathrm{~m} 3 /$ hours which treatment cost $\mathrm{Rp} 1.478 / \mathrm{m} 3$ and $60,96 \%-94,00 \%$ removal efficiency of macro-pollutants. CBA catalytic ozonation reported here is very efficient and environmental friendly for treatment hospital waste water. Electricity consumption for CBA operations is relatively low compared to conventional installed technology so that it can be an alternative in the effort to realize the development of low carbon communities in the wastewater treatment process.

\section{Acknowledgements}

The authors are grateful to Dr. Aris Mukimin, for his assistance and insightful input on the AOP reaction, and the technicians laboratory for their assistance with the analysis.

\section{References}

1. Hansen, K. M. S. et al. Ozonation for source treatment of pharmaceuticals in hospital wastewater - ozone lifetime and required ozone dose. Chem. Eng. J. (2016).

2. Berto, J. et al. Ecotoxicology and Environmental Safety Physico-chemical , microbiological and ecotoxicological evaluation of a septic tank / Fenton reaction combination for the treatment of hospital wastewaters. Ecotoxicol. Environ. Saf. 72, 1076-1081 (2009).

3. Kovalova, L. et al. Elimination of Micropollutants during Post-Treatment of Hospital Wastewater with Powdered Activated Carbon, Ozone, and UV. (2013).

4. Hansen, K. M. S. et al. Ozonation for source treatment of pharmaceuticals in hospital wastewater - ozone lifetime and required ozone dose. (2016).

5. Orias, F. \& Perrodin, Y. Science of the Total Environment Characterisation of the ecotoxicity of hospital effluents : A review. 455, 250-276 (2013).

6. Lee, Y., Kovalova, L. \& Mcardell, C. S. ScienceDirect Prediction of micropollutant elimination during ozonation of a hospital wastewater effluent. Water Res. 64, 134-148 (2014).

7. Escher, B. I. et al. Environmental toxicology and risk assessment of pharmaceuticals from hospital wastewater. Water Res. 45, 75-92 (2010).

8. Lucas, D. et al. Chemosphere Fungal treatment for the removal of antibiotics and antibiotic resistance genes in veterinary hospital wastewater. 152, 301-308 (2016).

9. Li, J., Cheng, W., Xu, L., Strong, P. J. \& Chen, H. Antibiotic-resistant genes and antibiotic-resistant bacteria in the effluent of urban residential areas, hospitals, and a municipal wastewater treatment plant system. 4587-4596 (2015).

10. Rame, Tridecima, A., Pranoto, H., Moesliem \& Miftahuddin. FLASH Technology: Full-Scale Hospital Waste Water Treatments Adopted in Aceh. E3S Web Conf. 31, (2018).
11. Rame, R. et al. High Performance Approaches on Wastewater Treatment Technologies in Hospital and Community Health Centre in Indonesia. in Proceedings The 7th International Symposium For Sustainable Humanosphere [ISSH]- 2017 185-191 (2017).

12. Lofrano, G. Green Technologies for Wastewater Treatment: Energy Recovery and Emerging Compounds Removal. (Springer, 2012).

13. Alexander, J., Knopp, G., Dötsch, A., Wieland, A. \& Schwartz, T. Science of the Total Environment Ozone treatment of conditioned wastewater selects antibiotic resistance genes, opportunistic bacteria, and induce strong population shifts. Sci. Total Environ. 559, 103112 (2016).

14. Chen, Y., Peng, R., Shen, T., Tong, S. \& Ma, C. A promising ozone-based advanced oxidation process for effective generation of hydroxyl radicals in acidic solution. Sep. Purif. Technol. 151, 269-275 (2015).

15. Rame, R. et al. Catalytic Ozonation Based Advanced Oxidation Process for Effective Treating Wastewater from Hospital and Community Health Centre Facility by Flash WWT Catalyst System in Indonesia. in International Conference of the Indonesian Chemical Society 2017. unpublished manuscript (2017).

16. Zhu, H., Ma, W., Han, H., Han, Y. \& Ma, W. Catalytic ozonation of quinoline using Nano-MgO : Efficacy, pathways, mechanisms and its application to real biologically pretreated coal gasification wastewater. Chem. Eng. J. (2017).

17. Quero-pastor, M., Valenzuela, A., Quiroga, J. M. \& Acevedo, A. Degradation of drugs in water with advanced oxidation processes and ozone. J. Environ. Manage. 137, 197-203 (2014).

18. Zealand, N. The study of hospital wastewater treatment by combined. 181, 627-632 (2012).

19. Comparison of Wastewater Treatment in Developed and Developing Countries. (2006).

20. Pai, T. Y., Tsai, Y. P., Lo, H. M., Tsai, C. H. \& Lin, C. Y. Grey and neural network prediction of suspended solids and chemical oxygen demand in hospital wastewater treatment plant effluent. 31, 1272-1281 (2007).

21. Qiu, G., Song, Y. \& Yuan, P. Notice of Retraction Effect of Organic Loading on Membrane Fouling in Membrane Bioreactor for Berberine Pharmaceutical Wastewater Treatment.

22. Kanakaraju, D., Glass, B. D. \& Oelgem, M. Heterogeneous Photocatalysis for Pharmaceutical Wastewater Treatment. (2013). 